Research, part of a Special Feature on Local, Social, and Environmental Impacts of Biofuels

\title{
Land-based Investments for Rural Development? A Grounded Analysis of the Local Impacts of Biofuel Feedstock Plantations in Ghana
}

\author{
George C. Schoneveld $^{1,2}{ }^{\text {Laura A. German }}{ }^{1}$, and Eric Nutakor ${ }^{3}$
}

\begin{abstract}
The rapidly growing biofuel sector in Africa has, in recent years, been received with divided interest. As part of a contemporary wave of agricultural modernization efforts, it could make invaluable contributions to rural poverty. Conversely, it could also engender socioeconomically and environmentally detrimental land use changes as valuable land resources are converted to plantation agriculture. This research analyzes the impacts and impact pathways of biofuel feedstock development in Ghana. It finds that companies are accessing large contiguous areas of customary land through opaque negotiations with traditional authorities, often outside the purview of government and customary land users. Despite lack of participation, most customary land users were highly supportive of plantation development, with high expectations of 'development' and 'modernization.' With little opposition and resistance, large areas of agricultural and forested land are at threat of being converted to plantation monoculture. A case study analysis shows that this can significantly exacerbate rural poverty as communities lose access to vital livelihood resources. Vulnerable groups, such as women and migrants, are found to be most profoundly affected because of their relative inability in recovering lost livelihood resources. Findings suggest that greater circumspection by government is warranted on these types of large-scale land deals.
\end{abstract}

Key Words: biofuels; dispossession; Ghana; land grabbing; land tenure; rural development

\section{INTRODUCTION}

An increasing number of countries around the world have started or are in the process of mandating the incorporation of renewable energy products into their energy matrix (REN21 2009). This is in large part driven by political and economic concerns in industrialized countries over excessive dependency on imported fossil fuels and the need to reduce carbon emissions. The adoption of blending mandates through the Renewable Energy Directive (RED) of the European Commission and the Renewable Fuel Standard (RFS 2) in the United States, in particular, has created sizeable and comparatively stable markets for biofuels. Although some developing countries share the concerns of industrialized countries, it is increasingly the new export opportunities that this trend inspires that are motivating their governments to embrace the renewable energy sector in general and firstgeneration biofuels in particular (Schoneveld 2010). It is generally perceived that developing countries, notably in Africa, are significantly more competitive in producing biofuels than industrialized countries, because of relatively low costs of production and the availability of cheap and agroecologically suitable land for the cultivation of biofuel feedstocks (FAO 2008, Fischer et al. 2009).

Seeking to capitalize on these opportunities many foreign companies have, over the past five years, acquired large tracts of land across Africa for the commercial cultivation of biofuel feedstocks, particularly for the oil seed bearing plant Jatropha Curcas L. (jatropha; Amigun et al. 2008, Cotula et al. 2008, Gordon-Maclean et al. 2009, Schut et al. 2010). These investments could contribute to improving the trade balance and provide African countries with much needed investment capital, while simultaneously contributing to energy security and rural development. It also presents a number of risks because many countries do not have comprehensive legal and institutional frameworks in place to regulate this type of landbased investment (Jumbe et al. 2009, Schoneveld et al. 2010). For example, there is emerging concern over the large-scale transfer of valuable land resources from customary land users to commercial enterprises, because of the loss of access to vital livelihood resources for the local poor, inequitable benefit capture, and environmental degradation. Although an increasing amount of literature is devoted to characterizing this trend and the underlying factors that are driving it (Kugelman and Levenstein 2009, von Braun and MeinzenDick 2009, Cotula et al. 2009, World Bank 2010a, Zoomers 2010), strikingly little evidence-based research has to date been conducted into the actual impacts and impact pathways.

Early efforts to introduce jatropha for use as a fuel in Africa, including Ghana, were typically promoted by nongovernment organizations through community-level cultivation, processing, and consumption. More recently though, jatropha is increasingly being adopted as a plantation crop, despite limited experience in the crop's propagation and management at a commercial scale. Along with countries such as Tanzania, Mozambique, Madagascar, and Ethiopia, Ghana is one of the primary investment destinations for commercial jatropha companies (CIFOR 2011). Although civil society in Ghana has cautioned against the surge of large-scale jatropha investments (see Nyari 2008, Amankwah 2009, Bull 2009, 
Nonor 2010; Civil Society Coalition on Land 2009, unpublished report), empirical evidence as to the precise scope, scale, and implications of these developments is limited. This article seeks to contribute to these research needs through a detailed case-study analysis of the local, social, and economic impacts of jatropha development in the Pru district of the Brong Ahafo region. By doing so, this article illustrates some of the challenges associated with fully capturing the rural development potential of this new wave of large-scale agricultural investments in Africa.

As a background, the article first discusses the development of plantation agriculture in Ghana and the potential opportunities and risks to Ghana's rural development. This is followed by the case study analysis. The wider relevance of findings from the case study is subsequently discussed by drawing on observations from other plantation sites visited in this research. The article concludes with a reflection on the potential rural development implications of large-scale plantation agriculture.

\section{BIOFUELS AND THE EVOLUTION OF PLANTATION AGRICULTURE IN GHANA}

Early attempts were made to develop large plantations for tropical export crops in Ghana under colonial rule. It was, however, not until Ghana's independence in 1957 that the development of large-scale mechanized agriculture became a policy objective (Akoto 1987). Most of these early, often stateled, initiatives were unable to weather the neoliberal market reforms of the 1980s, in which state support was removed, undermining their ability to withstand increasing international competition (Amanor and Pabi 2007). The only notable projects from that era that are still operational are four oil palm projects and one rubber project, with estates ranging in size from 2500 to 13,000 ha, concentrated in southwestern Ghana. These projects all benefited significantly from the support of foreign private and, in some cases, donor capital (Gyasi 1996), and are all majority foreign-owned.

In the 2000s, plantation agriculture in Ghana became the object of renewed interest by the private sector. This initially targeted the horticultural sector, particularly for the cultivation of pineapple for export to the European market. Although smallholders have historically dominated pineapple cultivation in Ghana, since 2003 shifting European demand to a pineapple variety that is more technologically intensive to cultivate and the increasing adoption of stricter health and fair trade standards, e.g., GlobalGAP, have tended to favor better capitalized operators (Takane 2004, Fold 2008, Jaeger 2008). At present, this market is dominated by a dozen medium to large-scale farms, up to 3500 ha in size, concentrated in southcentral Ghana. However, despite the prevalence of commercial farming in the horticultural and oil palm sectors, smallholders in Ghana account for approximately $90 \%$ of landholdings and $80 \%$ of agricultural output, and continue to contribute significantly to the output of the aforementioned sectors (Chamberlin 2008).

Despite these early developments, it was not until global oil prices starting showing signs of escalating in 2006 that companies showed a real interest in acquiring large tracts of land for plantation agriculture. At an unprecedented scale and pace, 20 commercial plantation companies, more than threequarters of which are majority foreign-owned, have since gained access to an estimated 1.184 million ha of land for the purpose of developing biofuel feedstock plantations in Ghana (G. Schoneveld and L. German, unpublished manuscript). This is equivalent to approximately $4.6 \%$ of the total land area and $8.8 \%$ of the area suitable for agriculture. Although leasehold contracts appear to have been signed between companies and traditional authorities for most of this land, in Brong Ahafo only a small proportion of these land lease agreements were in fact formally registered at the Lands Commission at the time of research (Brong Ahafo Land Registry 2009, unpublished data). Although only few formal leasehold titles have therefore been granted, companies do gain legal rights over the land, albeit subject to a higher risk of conflict, because unregistered contracts are legally enforceable under Ghanaian contract law. Although the general fiscal regime in Ghana is highly conducive for investments, there were no newly introduced government incentives or even a biofuel policy and framework that prompted this surge in investment. Of the 20 inventoried biofuel plantation projects in Ghana, 13 focused on the cultivation of oil seed crops for biodiesel production, notably jatropha, four on starch and sugar crops for ethanol production, and three on woody biomass for, predominantly, electricity generation (G. Schoneveld and L. German, unpublished manuscript).

The largest number of projects are located within the forest to savanna transition zone (Fig. 1). This area is an agroecological zone located between the humid tropical areas in southern Ghana and the dry savannas in the north, comprising the northern stretches of the Ashanti region and most of the Brong Ahafo region. This area is especially suitable for large-scale agricultural enterprise because of relatively favorable rainfall regimes (1200 - $1500 \mathrm{~mm}$ per annum and relatively low rainfall variability), relative accessibility to key markets, and low population densities enabling access to large contiguous areas of land at low cost.

\section{THE RISKS AND OPPORTUNITIES OF PLANTATION AGRICULTURE TO GHANA'S RURAL DEVELOPMENT}

Although Ghana has some experience with plantation agriculture in its southern regions, the unprecedented magnitude of investment commitments for large-scale biofuel projects in recent years could lead Ghana into uncomfortable territory. On the one hand, most government ministries in 
Fig. 1. Distribution of biofuel feedstock plantations $>10,000$ ha in size.

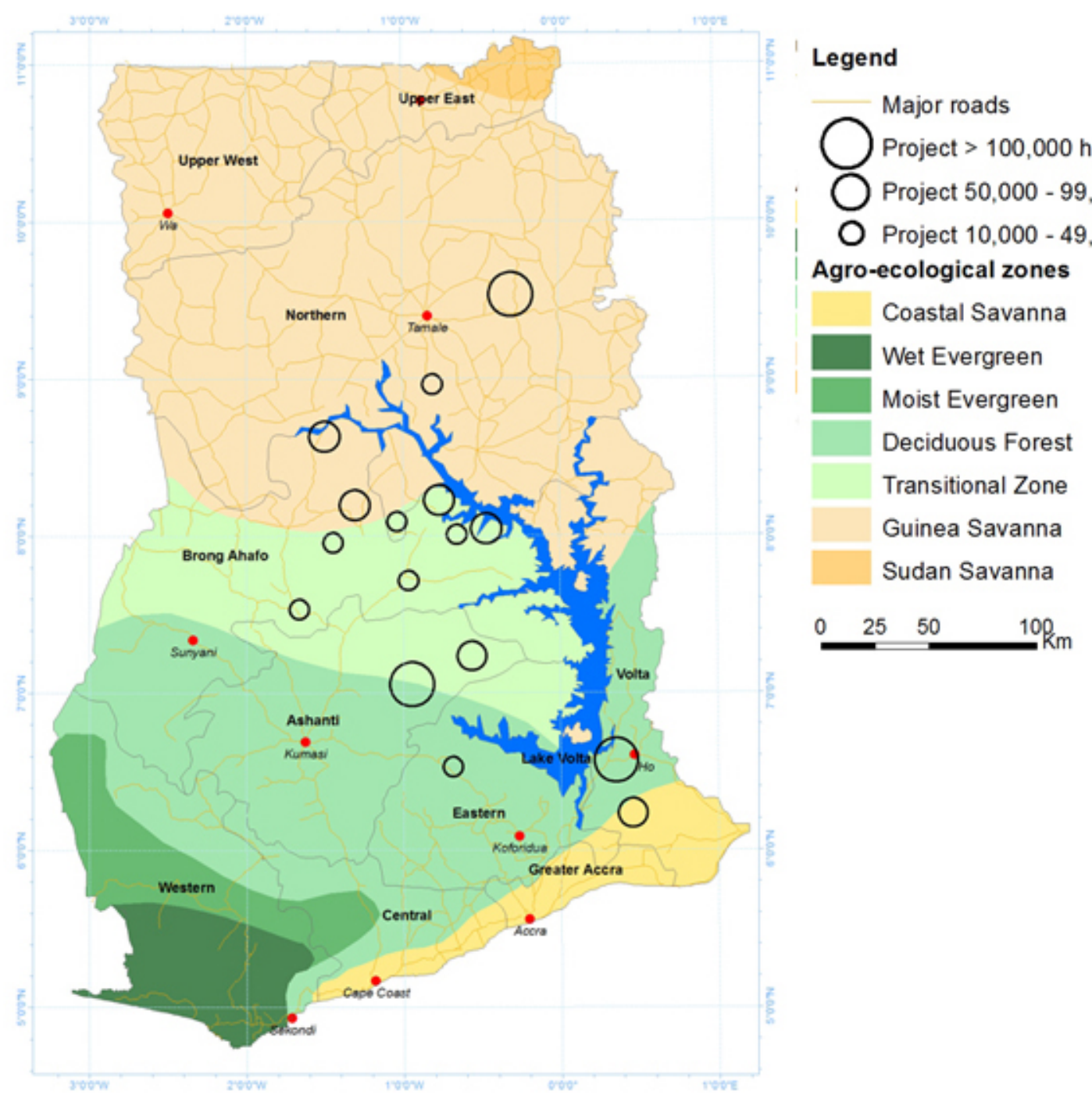

Source: Authors; Agro-ecological zones adapted from FAO 2004

Ghana have embraced this development for its potential to contribute to ongoing efforts to promote rural development through the modernization and diversification of the agricultural sector. The agricultural sector is the backbone of the economy, accounting for 34\% of GDP and employing 55\% of the economically active population (World Bank 2010b). Nonetheless, from being virtually self-sufficient in the 1970s, Ghana has become a chronic net food importer, unable to meet the domestic demand for staple foods such as wheat and rice with domestic production. Public and private underinvestment, poor market linkages, and barriers to adoption of modern inputs are considered to be key factors underlying Ghana's poor agricultural productivity (Seini 2002, Benin et al. 2009, Wolter 2009). Increases in production are, therefore, typically associated with an expansion in the area under cultivation rather than gains in land use efficiency (Quaye et al. 2010).

Perpetuated by the relatively high cost of industrial inputs and poverty, the level of agricultural intensification is low, with most smallholders practicing the traditional system of rotational bush-fallow. This is a form of shifting cultivation whereby land is cleared and burnt for the cultivation of specific crops and is subsequently left fallow for typically two to five years before being brought back into use. Although this system can be relatively sustainable at low population densities, land constraints are considered by some to be too high in much of Ghana for this farming system to be able to sustain the needs of a growing population (Ardey Codjoe 2010, Quaye et al. 
2010). Seeking to address these concerns, Ghana's most recent Growth and Poverty Reduction Strategy (GPRS II, 2006-2009) and Food and Agriculture Sector Development Policy (FASDEPII, 2007) consider agricultural modernization as a primary means to engender inclusive economic growth and structural transformation in rural areas. One of the key action points in these plans is to enhance private sector competitiveness by promoting investments in commercial farming and in outgrower schemes. With foreign direct investments considered to be critical in achieving these objectives, the government seeks to improve investment conditions by, inter alia, investing in infrastructure, deepening its integration into global markets, and facilitating investor access to land, e.g., through land banks.

Considering, however, the rather limited success of the Ghanaian government and its donors in realizing agricultural modernization and commercialization objectives both historically and in recent times (Akoto 1987, Wolter 2009), and its consistency with prevailing development strategies, the rather spontaneous interest by foreign investors in the biofuel sector could be perceived as a blessing. Because many of these investments are targeting areas in the forest to savanna transition zone and to some extent also the northern SudanoSahelian regions, this trend could serve to reduce the northsouth economic divide. Historically, all major cash and export crop industries have been concentrated in the southern regions, and poverty and subsistence agriculture in the northern regions (Sutton 1989, Wardell 2006). Enhancing agricultural productivity and value addition in these areas could be instrumental for reducing both national food insecurity and rural poverty. In this regard, there are some positive examples from previous experiences with plantation agriculture in Ghana. For example, it has been shown that as a result of improvements in infrastructure and increased availability of agricultural inputs, smallholders tend to intensify production (Tripp 1993, Brown and Amanor 2002), and increases in the availability of labor and demand for food products has been shown to incentivize smallholders to increase output (Amanor and Pabi 2007). However, the most direct contribution of large-scale plantation projects to rural development is arguably in the generation of new sources of income, for example, by leasing out land, participating in outgrower schemes, and plantation employment (FAO 2008, von Braun and Meinzen-Dick 2009, World Bank 2010a). Greater access to off-farm livelihood opportunities, such as plantation employment, is frequently cited as particularly instrumental to rural poverty reduction, through, amongst others, enhancing livelihood resilience to shocks due to income diversification and enabling households to invest surplus income in agricultural production (Reardon 1997, Ellis 1998, Barret et al. 2001, Lansing et al. 2008).

Such promises are countered with concerns, particularly in regards to early evidence that large-scale land acquisitions for plantation agriculture tend to displace customary land uses (Cotula et al. 2009, Sulle and Nelson 2009, Zaugg 2009, FIAN 2010, World Bank 2010a). The threat that rights to land are violated is especially pertinent to sub-Saharan Africa, where formalized rights to land in most countries range from $2 \%$ to $10 \%$ of the total land area (Deininger 2003). Although customary rights to land are afforded legal recognition in most countries, the failure to formalize these claims undermines security of tenure. Although this need not be problematic when pressures on and conflicts over land resources are low, increasing competition over land incentivizes the exploitation of legitimate, e.g., chiefly, authority, tends to drive land concentration, and threatens the continued access among often marginalized customary land users to crucial livelihood resources (Woodhouse 2003, Richards 2005, Toulmin 2008, Peters 2009, Amanor 2010). Consequently, the displacement of customary land uses for plantation agriculture could exacerbate rural inequalities (Cotula et al. 2008, Poulton et al. 2008, Hayami 2010, World Bank 2010a), thus conflicting with rather than supporting government policies to modernize subsistence agriculture.

The risk that the wholesale alienation of customary land for plantation agriculture infringes on customary land rights is equally pertinent to Ghana, where approximately $78 \%$ of land is under customary ownership (Deininger 2003). Unless acquired by the government through the right to eminent domain, as per the Ghanaian Constitution (1992), customary land cannot be permanently alienated, only formally allocated through renewable leases of up to 50 and 99 years' duration for foreigners and citizens, respectively. Traditional councils, typically comprised of a paramount chief and village elders, are the 'allodial title holders' and are, in this capacity, bestowed with the sole authority to negotiate and approve the allocation of customary land (Administration of Lands Act 1962). Customary land users, who often lack documented rights to land, are therefore often at the mercy of the traditional council's capacity and will to act in accordance with their fiduciary responsibilities (Blocher 2006, Grischow 2008, Ubink and Quan 2008, Berry 2009). New opportunities for extracting rents by elites from allocating large areas of customary land to commercial projects may be detrimental to the livelihoods of those who depend on that land.

To enhance tenure security, and enhance the downwards accountability of chiefs, the World Bank has since 2003 supported the Land Administration Project (LAP). One of the key components of the LAP is to establish Customary Land Secretariats (CLS) in traditional areas, which are tasked with, amongst others, registering individual claims to land, dispute resolution, and land use planning. However, these secretariats have only been established in a fraction of Ghana's traditional areas (World Bank 2010c). With participation in the project voluntary and demand driven, many traditional councils are disinclined to adopt new land management structures that risk 
circumscribing their authority and control over land (Ubink and Quan 2008; Project Director 2009, Land Administration Project, Accra, personal communications).

In addition to its socioeconomic implications, extensive conversion of existing land uses to plantation monoculture could also engender widespread environmental degradation, with subsequent socioeconomic repercussions. Because of extensive vegetation clearing and the adoption of monoculture, commercial plantations typically support considerably less (agro-) biodiversity than traditional farming systems and are often accompanied by loss of native forest and vegetation (Clay 2003, Poulton et al. 2008, Gibbs et al. 2010). With approximately $74 \%$ of forests in Ghana under no legal protection and the largest areas of land classified as forests located in the forest to savanna transition zone (calculations based on ESA 2006), the conversion of large contiguous areas of land to plantation agriculture could have far-reaching environmental implications.

\section{METHODOLOGY}

The research, conducted between June and August of 2009, comprised of three distinct phases aimed at capturing multiscale processes, e.g., national, regional, and local. The first phase consisted of semistructured key informant interviews and secondary data collection in Accra. Interviews were conducted with officials from relevant government institutions and civil society organizations to gain insights into relevant trends and their policy, regulatory, and institutional implications. Subsequently, visits to nine biofuel plantations were carried out in the central regions of Brong Ahafo and Ashanti, which were identified as areas with the highest concentration of biofuel investments. Interviews with representatives of only three companies were carried out, because of reluctance by many to participate in the research. The company responsible for the development of the plantation that is the subject of the detailed impact assessment was unfortunately unavailable for an interview. The company indicated that it wished to keep a 'low profile' for the time being and was, therefore, reluctant to have details surrounding its activities made public. As a result, the company was unable to clarify and/or explain field research findings and interpretations. Site visits, combined with focus group discussions with affected communities and interviews with the traditional leadership, were therefore the major sources of information on processes of plantation establishment and potential social, economic, and environmental impacts of plantation development. Additionally, various district and regional government institutions were consulted to corroborate and gain further insights into key establishment processes for the assessed biofuel developments and the role of different government actors therein.

On the basis of findings from key informant interviews at diverse levels, the research team sought to identify a plantation that was both representative of land use systems in the wider region being shaped by plantation agriculture and sufficiently advanced to enable the preliminary assessment of impacts. A 14,000 ha jatropha plantation, of which some 780 ha had been cleared for cultivation at the time of research, located in the Pru district of Brong Ahafo, was selected for a more comprehensive impact assessment. From discussions with the paramount chief, the traditional council, village chiefs, and community members, two broad stakeholder groups directly affected by the plantation were identified: (i) those employed at the plantation, originating from various areas in the district; and (ii) those losing land to the plantation, originating at the time of research largely from three communities. Within the latter group three subgroups were identified, namely, women, native inhabitants, and settler/migrant farmers. A total of 10 focus group discussions were subsequently held with the different groups. From information obtained from these sessions, the generic household questionnaires were adapted to ensure unique local issues were suitably captured. From a total sample size of approximately 120 employees, household surveys were conducted with 31 employees, 16 of which resided in the affected villages, constituting the entire subgroup sample frame, and 15 in other surrounding villages. From the land-losing household group, 63 household questionnaires were conducted from a total sample size of 69 . It was not possible to survey all households because some had since migrated or were otherwise unavailable.

\section{CASE STUDY BACKGROUND}

The case study plantation is located in northeastern Brong Ahafo, in the newly formed Pru district, with a total population of 93,857 and a population density of 42.8 per $\mathrm{km}^{2}$ (Medium Term District Water and Sanitation Plan, Pru District Assembly 2009, unpublished report). The district consists of four traditional areas, whose paramount chiefs rule from the towns of Abease, Konkoma, Prang, and Yeji. As part of the so-called 'yam-belt,' yam cultivation is the most important livelihood activity in the district, followed by the cultivation of cassava. Approximately $66 \%$ of the population depends on agriculture as their primary livelihood activity, and the remainder largely on fishing from the Volta Lake and smallscale trading (Ministry of Food and Agriculture, Pru district 2009, unpublished report). With a real GDP per capita of approximately 195 Ghanaian Cedi (equivalent to US\$131 on 1 January 2011) per annum, approximately half the national average, poverty rates are comparatively high (World Bank 2010b; Medium Term Development Plan, Pru District Assembly 2006, unpublished report).

There was no evidence prior to 2007 of large-scale commercial farming operations in the area. Between 2007 and 2009, however, four commercial agrobusinesses gained access to land in the district, three for the cultivation of jatropha and one for sugarcane. The companies gained access to land for a total of six different sites, which together covered an area of 
up to 152,500 ha, equivalent to $69 \%$ of the district's total land area. It was, however, not possible to ascertain whether all six leasehold agreements were formalized through a contract; this could only be verified for 77,500 ha, consisting of four sites with areas of 12,000 ha, 13,500 ha, 14,000 ha, and 38,000 ha (District Planning Officer 2009, District Assembly, Pru district, personal communication; Director 2009, Ministry of Food and Agriculture, Pru district, personal communication; Regional Land Commission Registry 2009, Sunyani, unpublished data). Another 70,000 ha and 5000 ha were reportedly also accessed, though it could not be ascertained whether these were bound by contracts or were solely good faith agreements. All sites were located on customary land, through which access was negotiated with relevant traditional councils. Cultivation activities were taking place at four of the six sites.

At the case study site, an area of approximately 14,000 ha was allocated in 2008 to a foreign biofuel company to cultivate jatropha. The traditional area where the company obtained land consists of six villages and a few small hamlet communities and is used periodically by nomadic herdsmen (Fulani). Aside from the native Brono ethnic group, a large proportion of the population consists of migrant farmers from northern ethnic groups, mainly Kokombas, Sisalas, and Dagaabas, most of whom settled in the area in the late 1980s. Migrant groups or 'settlers' obtained the unrestricted right to clear virgin land for cultivation from the traditional council, in exchange for an annual token of allegiance. In the case of the main settler village, this takes the form of 10 tubers of yam and two bottles of schnapps per household, and one sheep from the entire community.

Almost the entire population in the traditional area is engaged in traditional bush-fallow agriculture, with yam, like the rest of the region, being the key income earning crop. The land allocated to the company can be considered a forestagriculture mosaic, characterized by patches of open and closed woodlands, herbaceous and woody fallow, and small agricultural plots. Along the banks of the main rivers on the southern and western ranges of the traditional area are galleries of more densely vegetated forests. Because the soils around these rivers are heavily waterlogged, making them unsuitable for yam, these areas are not actively cultivated.

In regards to the process for accessing land, the traditional authorities were, according to their accounts, directly approached by the company without any government intermediaries. The traditional council was extremely receptive to the project, because it would "bring development and create jobs for the youth" and "government and company representatives will come live in our village" (Paramount Chief 2009, personal communication). Moreover, the council argued that the "profit from the company is far, far better than the [yearly] homage paid by the migrants." Presented by what appeared to be a fixed and standardized contract, the traditional council entered into a revenue-sharing agreement with the company for $25 \%$ of the profits from jatropha cultivation and the construction of new boreholes in the villages, in return for a 50-year renewable lease. Similar agreements were made by the company at its 4 other plantation sites. At this site, a verbal agreement was purportedly made for at least $75 \%$ of the plantation workforce to be residents of the traditional area, though this was not recorded in writing. There were no arrangements made for compensating potentially adversely impacted households.

At the time of research, the company had not obtained environmental permits for any of its sites, as is legally required when clearing more than 40 ha of land (Regional Director 2009, Environmental Protection Agency, Sunyani, personal communication; Environmental Protection Agency, unpublished data). Although the Environmental Protection Agency (EPA) was, after a year of operations, made aware of this, it did not order the company to cease their activities, but instead requested the company to conduct an environmental impact assessment for the land not under cultivation. At the time of research there was no evidence of on-the-ground assessments having been conducted. According to the Regional Director of the EPA, he did not wish to "obstruct development" by issuing a stop order. The District Assembly and district office of the Ministry of Food and Agriculture (MOFA) were also aware of this, but, justified in similar fashion to the EPA, did not further pursue the issue. Arguably, there were some conflicts of representation and interest in the case of MOFA, with one of its senior employees employed on the side as an 'agronomic consultant' by the company.

\section{LOCAL IMPACTS OF PLANTATION AGRICULTURE}

\section{Land use change}

The company commenced land preparation activities in mid-2008, having cleared an area of 960 ha by May 2010. Figure 2 shows the plantation area, with green shades depicting vegetation and pink/purple shades recently cleared land, which are typically under cultivation or are recently fallowed. The company plans to steadily expand the plantation westwards toward the traditional area's main settlements, with a targeted 14,000 ha under cultivation before the end of 2014. In late August 2009, when field research was conducted, the total cleared area was estimated at 780 ha (calculated from analysis of Landsat Imagery). An estimated $46 \%$ of this area (359 ha) was not considered to be part of the active farming system prior to conversion. This is calculated by subtracting the total area of affected land under usufruct rights, derived from household surveys, from the total area cleared by the company. As a common pool resource, mostly for the collection of forest products and hunting, no individual households held exclusive use rights to this land. These areas were by and large under open or closed forest cover, albeit in some parts degraded from overexploitation. 
Fig. 2. Band 5, 4, 3 false color composite of plantation area (path 194, row 54).

\section{October 14, 2008}

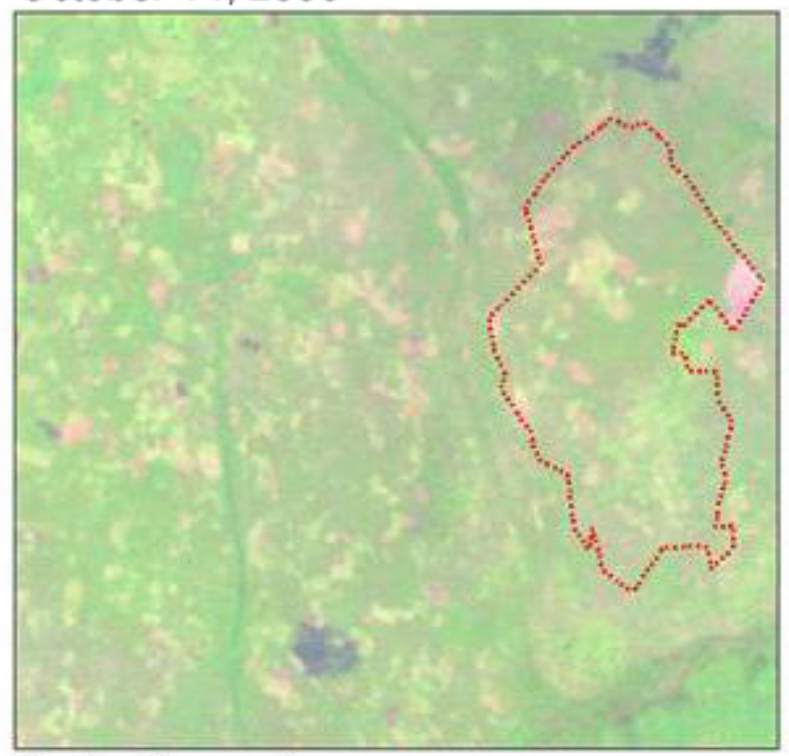

May 13, 2010
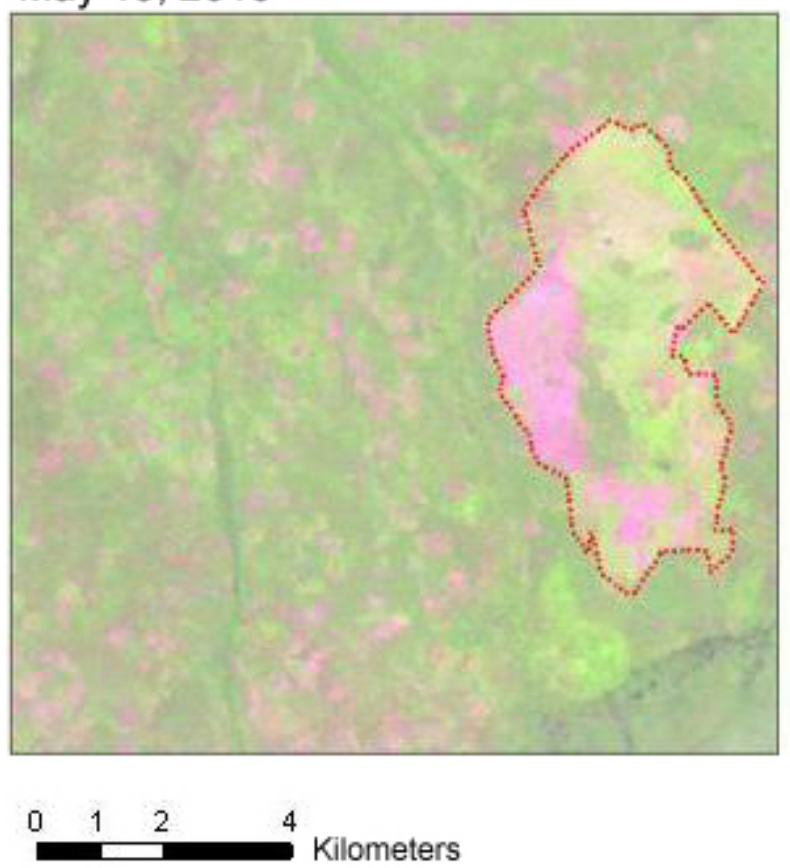

Area Cleared on May 13, 2010

Source: USGS

Both images constructed from Landsat 7 ETM; 194/54
The remaining 54\% (421 ha) of the land was being used for bush-fallow agriculture, consisting of actively cultivated cropland and fallow land. A total of 69 households, from three different villages, claimed usufruct rights to that land, having in the past been acquired either through inheritance, occupation through land clearance rights, allocation by the chief, or gift/sale. Approximately 19\% (80 ha) of this land consisted prior to conversion of so-called yam plots. These are typically the most important plots to the household, because the primary cash and staple crops are cultivated here, generally controlled by the head of household. Another 24\% (101 ha) of this land was used to grow other crops. Men in the communities actually considered these plots to be fallow, whereas for women these were considered the focus of their farming activities. Typically, these plots are acquired by women after having taken over the yam plots, often growing various subsistence crops, largely for household consumption. After one or two years of use, these plots are left fallow for a period ranging from 2 to 10 years, depending on total household landholdings. In this system of farming, tree stumps and rootstocks are often preserved, allowing woody vegetation to regenerate more rapidly. This facilitates plot rehabilitation before it is brought back into production. True fallow constituted approximately $57 \%$ (240 ha) of the land under user rights.

The 780 ha that were cleared directly impacted the landholdings of 69 households. None of these households participated in land negotiations, formally acquiesced to losing their land, or received any form of compensation for their loss. Their first knowledge of the plantation came in 2008 when the village chiefs informed them not to return to their land after harvesting their yam; land users had no prior contact with the company. For villages 1 and 3, land loss directly affected $41 \%$ and $51 \%$ of households, respectively (Table 1). The converted area was for these communities the most suitable and proximate area of land for cultivation, considering the heavily waterlogged and rocky soils around both villages. A smaller number of households from a third village (village 2) were active in this area.

By 2009, the average household landholdings had reduced by $61 \%$ (Fig. 3). Another $16 \%$ of the total landholdings of affected households had been earmarked by the company for conversion after the second and final yam harvest of 2009 , which was due to commence just following the time of research. Although ultimately losing more than three-quarters of their landholdings, only 18 households were able to gain access to replacement lands, constituting an area of only $12.6 \%$ of total initial landholdings. The average total household landholdings reduced from 26.1 acres to 12.7 acres, which by the end of 2009 was expected to have reduced to 8.5 acres. Seven households became landless as a result of plantation development. 
Table 1. Population information of affected communities.

\begin{tabular}{lccccc}
\hline \hline & Total Population ${ }^{\dagger}$ & Number of HH & $\begin{array}{c}\text { Proportion } \\
\text { Native HH in } \\
\text { Village }\end{array}$ & $\begin{array}{c}\text { Number of Land } \\
\text { Losing HH }\end{array}$ & \begin{tabular}{c} 
Proportion Total Posing Land $\begin{array}{c}\text { Proportion of land } \\
\text { Losing HH that } \\
\text { are Native }\end{array}$ \\
\hline Village 1
\end{tabular} Village 2 $^{\text {Village 3 }}$ \\
\hline
\end{tabular}

${ }^{\dagger}$ Population data from Medium Term District Water and Sanitation Plan, Pru District Assembly, 2009, unpublished report.

$\$$ These proportions are based on information provided by the respective village chiefs.

$\S$ Only 32 households were surveyed in this village, because of the temporary absence of some household heads at the time of research. All land losing households were surveyed in the other villages.

Fig. 3. Changes in average household landholdings by community.

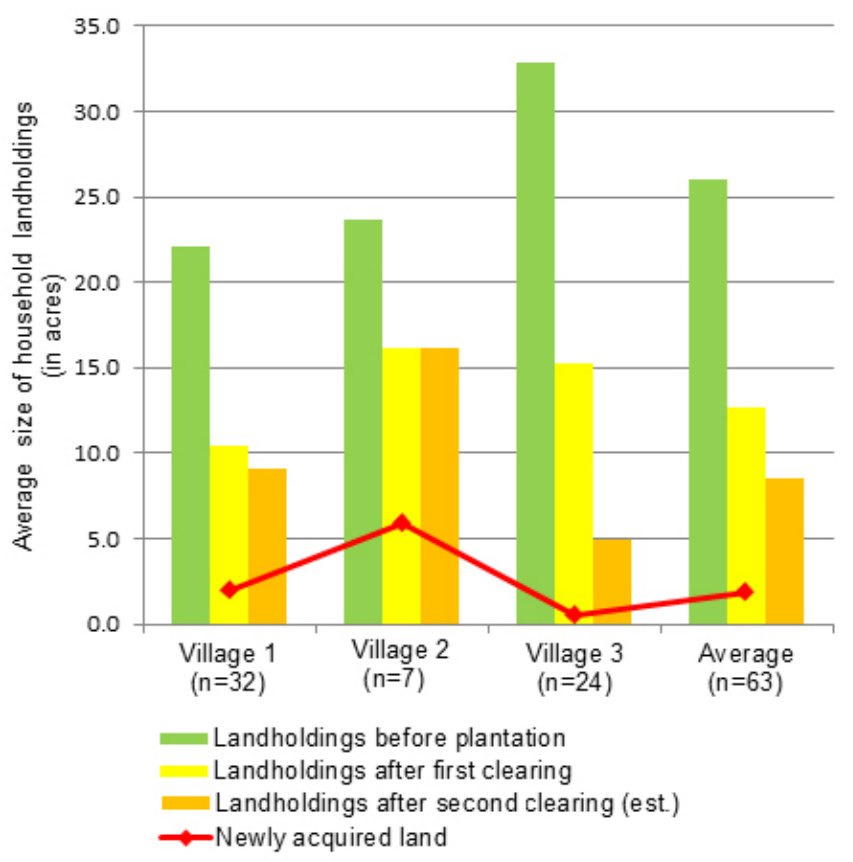

The extent of land loss and ability to obtain replacement land differed greatly between villages. In the case of village 2 , comprised entirely of settler farmers, households had little problem obtaining replacement land because of the relatively small proportion of affected households in the village. Four out of seven households secured new land from fallow land gifted to them by other community members. In village 1 , where land loss was most extensive, only 12 out of the 32 surveyed households were able to recover new land. However, eight of these households were native inhabitants of the community (out of 13 native households losing land), while only four were settler farmers (out of 18 settler households losing land), illustrating the higher land recovery rate among native inhabitants. From all the households gaining access to new land, native households recovered on average four acres of land, whereas settler farmers recovered 1.3 acres of land. According to respondents, because of the absence of suitable and available land, all replacement land was in the form of fallowed land obtained from other community members, sometimes enabled through cash payment. Settler farmers perceived a bias in the reallocation of land by native households in favor of other native households, illustrating the role of ethnicity and social networks in the capacity to obtain new land. In village 3, where all affected households were settler farmers, only 2 out of the 24 households were able to obtain replacement land.

The key barrier to obtaining new land is the lack of suitable land. For example, $67 \%$ of households cited land scarcity resulting from plantation development as the primary barrier to land recovery. For villages 1 and 3, most of the remaining lands are located either in heavily waterlogged or rocky areas, unsuitable for this type of farming system, or located too far from settlements to be considered viable. Even for those that did obtain new land, $50 \%$ considered this land to be of lesser suitability than the land they lost to the plantation. Another $13 \%$ of households considered lack of money to buy new land as the primary constraint, while $11 \%$ considered there not to be any barriers and $7 \%$ having made no attempt.

The primary livelihood activity for $95 \%$ of respondents before land loss was yam cultivation, with maize and cassava also serving as key cash crops. Although these crops were mainly considered to be men's crops, women were responsible for a range of secondary cash and staple crops, especially 
groundnuts, peppers, okra and tomatoes. Although cultivated predominantly for household consumption, these crops were also said to play a key role in providing cash income to cater for everyday household needs. In addition to farming, forestry activities were integral to most household livelihood portfolios. Besides firewood, most households depend on beans from the locust bean tree (Parkia biglobosa), which is fermented into a highly nutritious seasoning, locally referred to as "dawa dawa," nuts from the shea tree (Vitellaria paradoxa), charcoal production, which is the main income generating activity in the dry season for many households, medicinal plants, mushrooms, and small game. The locust bean and shea tree are considered especially important, for they typically provide a significant proportion of women's cash income. Charcoal, despite being an important source of income in many areas of Brong Ahafo, was considered to be the least important forestry activity, one only the youth engage in during the dry season. However, some households indicated it to be a desirable fallback option following land loss, despite its more limited availability.

In response to land loss, although the composition of household livelihood portfolios did not change substantially, marked reductions were observed in some activities (Table 2). Although a few households ceased farming altogether, principally as a result of becoming landless, and others stopped harvesting forest products, because of a reduction in forested land, these remain the primary livelihood activities for most households. However, most households did experience substantial declines in the contribution of these activities to their livelihood. As a result of smaller landholdings, most households reduced the area they had under cultivation and/ or returned prematurely to fallowed plots, which will contribute to reduced yields over time. Other households who lost only fallowed land to which they were not immediately planning to return did not yet experience a decrease in farm output, but will likely feel the effects of reduced landholdings over time as they search for suitable new land to bring into production.

Although the company only occupied yam plots once the yam harvest for the year was completed, other crops, many of these women's crops, were ploughed under prior to harvesting. Furthermore, after land loss, women had access to significantly smaller areas of land for their agricultural activities because, in many cases, the yam plots they would have used for their activities were already taken over by the plantation. This impact on women's cash income earning potential is compounded by the fact that most women experienced in particular marked declines, estimated through focus group discussions at 70 to $90 \%$, in the amount of beans from the locust tree and shea nuts they can collect, process, and market.
Table 2. Changes in livelihood portfolios $(n=63)$.

\begin{tabular}{lccc}
\hline \hline $\begin{array}{l}\text { Livelihood } \\
\text { Activity }\end{array}$ & $\begin{array}{c}\text { \% of HH } \\
\text { participating } \\
- \text { Before }\end{array}$ & $\begin{array}{c}\text { \% of } \mathrm{HH} \\
\text { participat- } \\
\text { ing } \\
\text { - After }\end{array}$ & $\begin{array}{c}\text { \% of } \mathrm{HH} \\
\text { experiencing a } \\
\text { decrease in } \\
\text { activity's } \\
\text { contribution to } \\
\text { livelihood since } \\
\text { plantation } \\
\text { establishment }\end{array}$ \\
\hline 1. Agriculture & 100 & 87 & 73 \\
2. Forest Products & 97 & 89 & 98 \\
3. Livestock & 21 & 29 & 0 \\
4. Off-farm & 3 & 10 & 0 \\
\hline
\end{tabular}

To cope with lower agricultural incomes, a few households did however manage to expand the scope of their livelihood activities to include livestock rearing and off-farm activities such as salaried employment at the plantation (three households) and small-scale trading of consumer goods (one household). Nevertheless, lack of skills and financial capital are considered by most households to be the most significant barriers to livelihood diversification. This high ex ante dependency on on-farm activities and low capacity to diversify makes households especially vulnerable to external shocks that reduce the availability of important livelihood resources.

The effects of land loss and inability to adopt new livelihood strategies has resulted in a decline in the standard of living for $73 \%$ of households, according to a host of locally salient indicators (Table 3). Households that did not experience a change were by and large those who lost fallow land they were not immediately planning to bring back into production, indicating that the use of this land will now intensify over time. The most cited changes to their livelihoods included, in order of frequency, loss of access to forest products, decreased availability of land, increased time spent gathering firewood, and loss of income. However, the primary underlying cause for lower living standards was considered to be the lower yields from agriculture and forestry, which in turn reduces household spending power and increases dependency on external food sources.

Although only a small proportion of the surveyed households indicated an impact on social relations, some tensions resulting from plantation development were nonetheless apparent. For example, tensions between settler and native community members had emerged from the suspicion among settlers that their land had been specifically targeted for plantation development. As a result of land loss and the inability to acquire new land, most settler farmers in village 1 and village 3 were considering migrating back north in search of new land. Because settler farmers contribute significant communal labor for community development projects and land clearing, native 
households are concerned this will place an additional burden on the household and reduce farm productivity.

Table 3. Perceived livelihood impacts of land loss $(n=63)$.

\begin{tabular}{lccc}
\hline \hline Variable & $\begin{array}{c}\text { Negative } \\
(\% \text { of } \\
\text { Households })\end{array}$ & $\begin{array}{c}\text { No Change } \\
(\% \text { of } \\
\text { Households })\end{array}$ & $\begin{array}{c}\text { Positive } \\
(\% \text { of } \\
\text { Households })\end{array}$ \\
\hline $\begin{array}{l}\text { 1. Access to } \\
\text { Forest Products }\end{array}$ & 95 & 5 & 0 \\
$\begin{array}{l}\text { 2. Land } \\
\text { Availability }\end{array}$ & 81 & 19 & 0 \\
$\begin{array}{l}\text { 3. Time to Gather } \\
\text { Firewood }\end{array}$ & 74 & 24 & 2 \\
$\begin{array}{l}\text { 4. Income Level } \\
\begin{array}{l}\text { 5. Food Security } \\
\text { 6. Ability to }\end{array}\end{array}$ & 67 & 33 & 0 \\
$\begin{array}{l}\text { Support Children } \\
\text { 7. Social Relations }\end{array}$ & 61 & 39 & 0 \\
$\begin{array}{l}\text { Overall Standard } \\
\text { of Living }\end{array}$ & 73 & 39 & 0 \\
\hline
\end{tabular}

Discontent over loss of land in the three villages was remarkably not directed at the traditional council that gave away their land, or even at the company. The general sentiment appears to be that the "paramount chief cannot be challenged," because he, as the "land owner," is in his full right to allocate land as he considers necessary. This view is especially strong among settler farmers, most of whom felt it was never their land to claim in the first place. The district government appeared to show a similar deference to the authority of traditional councils. When a group of villagers expressed their concerns with the Pru District Assembly, for example, they were told to take it up with the paramount chief himself; according to Assembly representatives this was because they did not wish to meddle in chieftaincy affairs. Moreover, because employees from the district office of MOFA and the District Assembly had openly provided their support to the company, in one focus group discussion it was argued that "the company must then be a good thing."

In village 1 , however, it is the village chief that was held responsible for the plight of affected land users, because in their view it was he that was unable to negotiate a better deal for them, despite the fact that he was not directly involved in the land transfer process. Nevertheless, the vast majority of land losing households at the time of research did not express regret over the coming of the project, because it was anticipated that "development will come when the company starts making a profit." The most important developments households were typically hoping for included better schools and teachers, better medical care, and greater demand for food crops because of in-migration. However, very few households expected that the income allocated to the traditional council from these profits would be shared with the communities, just as the traditional annual homage to the council is not customarily shared.

\section{Impact of employment}

One of the key mechanisms through which the development of large scale commercial plantations can bring direct benefits to affected communities is through plantation employment. At the time of research the plantation employed 120 persons, ranging from part-time manual laborers commissioned specifically for clearing land to more highly skilled workers, e.g., tractor operators. The average wage for unskilled fulltime employees amounted to 75 Ghanaian Cedi (US\$ 50) per month. On the basis of district averages, this would constitute approximately $51 \%$ of the average household income (assuming a real GDP per capita of US\$ 131 per annum and an average household size of nine persons). On the basis of the employee surveys that were conducted, $67 \%$ of the 31 respondents considered plantation employment to have had a net positive impact on their livelihoods (Table 4). Few of these respondents, however, attributed this to an increase in income. Rather, the majority perceived the increase in security and stability of income flows to be the key contribution, increasing their capacity to consistently cover food, medical, and educational expenses. The employees that did not indicate an improvement in their livelihoods $(33 \%)$ had either 'mixed' sentiments about employment $(5 \%)$ or did not consider employment to have had any significant impact on their livelihoods $(28 \%)$. None of the respondents considered there to be a reduction in their standard of living from employment.

Table 4. Benefits of employment $(n=31)$.

\begin{tabular}{lc}
\hline \hline Variable & $\begin{array}{c}\text { Proportion of Affirmative } \\
\text { Response }\end{array}$ \\
\hline $\begin{array}{l}\text { 1. Increased stability and security of } \\
\text { income }\end{array}$ & $74.1 \%$ \\
$\begin{array}{l}\text { 2. Increased ability to cover medical } \\
\text { expenses }\end{array}$ & $66.7 \%$ \\
3. Increased ability to care for & $59.3 \%$ \\
children & \\
4. Increased food security & $53.6 \%$ \\
5. Increased income levels & $44.4 \%$ \\
6. Increased ability to save and/or & $29.6 \%$ \\
invest & \\
7. Increased social status & $25.9 \%$ \\
Improvement to overall standard of & $66.7 \%$ \\
living & \\
\hline
\end{tabular}

Prior to employment, $73 \%$ of respondents were engaged in subsistence farming as their primary livelihood activity, with the remaining respondents either owning small businesses or employed elsewhere as waged laborers. Almost all respondents previously involved in off-farm activities abandoned these activities once having gained plantation employment. For those employee respondents who were, on 
the other hand, previously engaged in farming activities only $10 \%$ stopped these activities altogether. It was found that farming activities remain important to household income and food security, with plantation employment typically complementing, rather than substituting, these activities. Because employees are typically household heads and young adults who contribute significant labor to household farming activities, a decrease in their engagement does place considerable strain on other household members, especially during land preparation and harvesting periods. Most employees bemoaned the lack of flexibility in unpaid leave to enable them to fulfill periodic household and communal labor commitments. In one community the inability of plantation employees to participate in the required communal labor activities caused a conflict that escalated to require police intervention. Such issues illustrate the potential incompatibility between traditional livelihood activities and social responsibilities on the one hand, and formal employment on the other.

Formal employment has the potential to contribute significantly to livelihood reconstruction efforts of land losing households. However, although the impact of employment is perceived to be generally positive, these gains do not appear to accrue substantially to households that have been affected by land loss. As previously discussed, only three land losing households (4\% of households) managed to secure employment at the plantation, despite ample interest in formal employment among affected households. In the three affected communities, a total of 16 employees (approximately 13\% of the labor force) were employed at the plantation, despite a reported verbal agreement between the paramount chief and company to provide preferential employment to neighboring communities. According to affected households, one of the key problems is that company administration, from where most recruitment is initiated, is based more than $20 \mathrm{~km}$ away.

This unequal distribution of costs and benefits is even better illustrated when assessing the opportunity costs of land, which we assess by comparing the net value of employment to the net value of displaced economic activities. Although beyond the scope of this research to conduct a thorough economic analysis, greater returns to land are obtained from primary cash crop cultivation than from employment, disregarding other economic values of displaced land and the distributional effects. For example, 1 ha of plantation provides 0.15 jobs (120 employees for $780 \mathrm{ha}$ ), which generates US $\$ 90$ per year (at an average income of US\$50 per month per employee). To enable this employment, approximately 80 ha of yam was displaced, which generates an average profit of approximately US\$ 1005 per annum per ha (on the basis of farmer estimates). Thus for an area of 780 ha, yam cultivation alone generates approximately US\$ 99 per ha per year $(110 \%$ the per-ha value of employment). Considering the value of other displaced cash and staple crops and forest products, the returns to land are far greater from prior land uses than from formal employment. According to three major biofuel companies in Ghana, however, labor intensity typically decreases to approximately 0.06 jobs per ha once the jatropha plants reach maturity, with seasonal hikes to 0.08 and 0.12 jobs per ha during harvesting months. This would imply that the per-ha value of employment will steadily decrease over time. An analysis of distributional effects is even more worrisome. Land losing households recuperated on average only US $\$ 2.26$ per ha per year directly through employment, only $2.3 \%$ of the value of displaced yam cultivation.

\section{DISCUSSION}

The immediate negative impacts experienced by households relate principally to their loss of access to land and forest resources and their limited ability or inability to access these resources elsewhere. Not only does this reduce the quality of their livelihoods in the absence of effective livelihood reconstruction efforts, but it will also likely place a strain on non-land-losing households because of enhanced competition over increasingly scarce land and forest resources. On the basis of the above results, it is likely to be the most vulnerable groups that lose out most in this process. Women and settler farmers, in particular, will not have the same capacity to access land and forest resources, which is likely to alter both inter- and intra-community dynamics as patterns of power and control change. The increasing land pressure in the area will undoubtedly exacerbate the process of land degradation on remaining land as cropping cycles shorten, soil fertility declines, and forests deplete through increased harvesting intensity. This is likely to have direct implications for agricultural and forest biodiversity, which, in turn, could bear negatively on the diversity of livelihood resources to which households have access. Such processes and related impacts are likely to intensify as the plantation expands and more land and forest resources are converted to plantation monoculture. Figure 2 clearly depicts the high concentration of agricultural plots in the direction the company is expanding. Based on average household landholding data and observed farming intensity in the area (derived from geospatial analysis), it is estimated that between 1500 and 1600 households will face land loss should the plantation area develop to its planned extent.

Many of these processes often play out when smallholder farming is displaced for commercial monoculture plantations. However, the lack of initiatives by this particular company to alleviate the impact of land loss significantly contributes to the population's current plight. For example, companyinitiated efforts to secure suitable replacement land for farming, provide agricultural inputs to offset the agronomic challenges and related costs associated with reduced fallow time, and cash compensation, as well as implement wellfunctioning preferential employment policies, could have 
contributed significantly to livelihood reconstruction. Although similarly detailed assessments were not carried out for other companies, on the basis of interviews at other communities, these problems appear to be widespread. Where such negative impacts are not as apparent is where companies make concerted efforts to restore ex ante levels of local food production. Although such companies tended to be those who had secured environmental permits, it is unclear whether this was due to company policies or the effectiveness of the environmental impact assessment process per se. Though an isolated case, one jatropha project in the Northern region reportedly actually contributed to increasing the acreage under food crops by providing inputs, designating plots on the estate for continued smallholder production, and facilitating access to agricultural machinery (Boamah 2010; Chief Executive Officer 2009, Biofuel Africa, personal communication; Executive Director 2009, Energy Commission, Accra, personal communications). Although some companies will be inclined to implement mitigation measures because of their own sense of corporate social responsibility, financing conditions, environmental permit conditions, or pressure from civil society, it is unlikely that such practices will be adopted by companies with poor corporate social responsibility track records in the absence of additional regulations or incentives.

Traditional councils could be another avenue through which affected persons could obtain recourse, when, for example, household-level compensation and various other developmental commitments are negotiated and formalized as part of the leasehold contract. However, at none of the nine plantations visited in this research was there any evidence of traditional councils consulting, or negotiating direct compensation on behalf of, their constituents. Presumably, the responsibility of some traditional councils to act in the interest of their constituents is compromised by the opportunities for personal enrichment or lack the capacity, e.g., legal literacy, to negotiate fair terms. In this case study, in particular, the traditional council harbored strong feelings of personal entitlement to manage, alienate, and profit from the land as they see fit. Unfortunately, this does not appear to be an isolated case, with similar processes having been observed in the oil palm (Gyasi 1996) and horticultural (Fold and Gough 2008) sectors and in the urban periphery (Kasanga and Kotey 2001, Wily and Hammond 2001, Ubink and Quan 2008). Given that communities at most of the visited plantations were generally receptive to the projects proposed in their areas and showed significant deference toward chiefly and government authority, it is unlikely that many affected persons will formally contest the expropriation of their land, despite having sufficient legal grounds to do so. The risk that unjust and legally contestable land alienations are not challenged through the judiciary is further compounded by the strong prodevelopment stance of district and regional governments and the limited capacity of affected persons to effectively claim their legal rights.
These observations illustrate, in particular, the need for more transparent and participatory negotiation processes, which fully account for the needs of all relevant stakeholder groups. Ideally, such negotiations would lead to binding agreements ensuring (i) loss of customary land uses key to food and income security are minimized; (ii) all economic losses are duly compensated for; (iii) alternative livelihoods at equal or greater value are secured; and (iv) meaningful cobenefits for local communities are realized, e.g., through value chain integration, infrastructure, and social services. It must be recognized, however, that the limited awareness of the true value of land, unrealistic expectations about future benefits, the weak negotiating capacity of traditional councils and customary land users alike, and the discursive politics of the negotiation encounter will undermine the effectiveness of local participation or local consultation efforts in leveraging more meaningful benefits and overcoming the elite capture of the benefits that do accrue. The threats this presents suggests the need for more direct intervention of key sectoral ministries in the land alienation process. However, as has been shown in other countries in which governments play a more active role in the negotiation encounter (German et al., in press), the effectiveness of the land alienation process may only be undermined and resulting social injustices legitimized by a political economy of government more aligned to the interests of the investor than the customary land user. Albeit theoretically justifiable, conflicting interests, systemic capacity constraints, and historically entrenched power relations limiting the check and balances on chiefly authority in Ghana will in practice likely limit the utility of public intervention. Bottom-up approaches to strengthen capacities to claim, by means of, for instance, legal empowerment initiatives support by civil society organizations, are likely to have an essential role to play in efforts to protect user rights. Efforts to leverage improved corporate practice, for example, by identifying potential synergies between market demands and domestic governance shortfalls, could also be explored, particularly market-based sustainability standards.

\section{CONCLUSION}

The case study analysis illustrates that corporate irresponsibility, poor regulatory enforcement, elite capture, and under-regulation of land deals can have severe implications for local land users. As communities lose access to vital resources, especially forests and land, it directly impacts on their food security and income earning potential. In areas where large-scale land transfers induce resource scarcity, capacity for livelihood reconstruction is severely undermined. Vulnerable groups, such as women and migrant farmers, are particularly impacted as a result of their comparatively insecure access to vital livelihood resources. On the other hand, formal employment on plantations was found to have had net positive livelihood impacts for employee households by enhancing the stability and security of income flows. Although this form of waged employment is unlikely to enable accumulation, it can be perceived foremost as an 
important consumption smoothing activity to complement, not substitute, traditional livelihood portfolios. However, with the value of directly displaced economic activities exceeding the direct economic returns of employment and limited numbers of losing households acquiring jobs, it raises the question of whether substituting smallholder agriculture for formal employment is an economically, not to mention socially, desirable proposition. Targeted development and risk mitigation interventions suitably adapted to unique local needs and realities are evidently required to ensure other cobenefits are effectively captured by negatively impacted households.

The evidence presented here suggests these new large-scale investments in plantation agriculture should justifiably be met with some circumspection. The potential magnitude of adverse impacts and the limited local economic gains calls into question some of the assumptions underlying prevailing rural development strategies not only in Ghana, but also in many other African countries. Foremost, the implicit assumption that private investment in large-scale plantation agriculture will make net economic contributions through the modernization of the rural economy needs to be qualified. It is only under the right set of legal, institutional, and politicaleconomic conditions that mutually advantageous coexistence between subsistence and commercial agriculture can be realized. Although there is ample space for the state in fostering these conditions, structural impediments, both in orientation and in capacity, currently threaten this coexistence. Consequently, this new wave of agricultural investments may in practice actually engender developmental outcomes that contradict rather than enable the achievement of extant policy objectives.

Responses to this article can be read online at: http://www.ecologyandsociety.org/voll6/iss4/art10/ responses/

\section{Acknowledgments:}

This paper has been produced with the financial assistance of the European Union, under a project entitled, 'Bioenergy, sustainability and trade-offs: Can we avoid deforestation while promoting bioenergy?' The objective of the project is to contribute to sustainable bioenergy development that benefits local people in developing countries, minimizes negative impacts on local environments and rural livelihoods, and contributes to global climate change mitigation. The project is managed by Center for International Forestry Research and implemented in collaboration with the Council on Scientific and Industrial Research (South Africa), Joanneum Research (Austria), the Universidad Autónoma de México and the Stockholm Environment Institute. The views expressed herein can in no way be taken to reflect the official opinion of the European Union. In addition to acknowledging the financial support of the EC, authors would like to express their gratitude to the many people that contributed to this research. Without the support of the Forest Research Institute of Ghana (FORIG) and its dedicated team this work would not have been possible. Specifically, we would like to thank Victor Agyeman, Kwame Oduro, Nana Derkyi, and Beatrice Darko-Obiri. Finally, we would like to extend our warm appreciation to the Government of Ghana for the willingness of many of its ministries and agencies to provide us with their valuable perspectives, information, and institutional support. Amongst these are the Ministry of Energy, the Energy Commission, the EPA, the GIPC, the Land Commission, the Pru District Assembly, and the Ministry of Food and Agriculture. The views expressed herein can in no way be taken to reflect the official opinion of the European Union.

\section{LITERATURE CITED}

Akoto, O. A. 1987. Agricultural development policy in Ghana. Food Policy 12(3):243-254. http://dx.doi.org/10.1016/0306-9192 (77)90024-0

Amankwah, A. A. 2009. Ghana: women lose their land to biofuel farms. Public Agenda, 16 March. [online] URL: http: //allafrica.com/stories/200903161744.html

Amanor, K. S. 2010. Family values, land sales and agricultural commodification in southeastern Ghana. Africa 80 (1):104-125. http://dx.doi.org/10.1353/afr.0.0158

Amanor, K. S., and O. Pabi. 2007. Space, time, rhetoric and agricultural change in the transition zone of Ghana. Human Ecology 35:51-67. http://dx.doi.org/10.1007/s10745-006-9081-6

Amigun, B., R. Sigamoney, and H. von Blottnitz. 2008. Commercialisation of biofuel industry in Africa: a review. Renewable and Sustainable Energy Reviews 12:690-711. htt p://dx.doi.org/10.1016/j.rser.2006.10.019

Ardey Codjoe, S. N. 2010. Population growth and agricultural land use in two agro-ecological zones of Ghana, 1960-2010. Regional Institute for Population Studies, University of Ghana, Accra, Ghana.

Barrett, C. B., T. Reardon, and P. Webb. 2001. Nonfarm income diversification and household livelihood strategies in rural Africa: concepts, dynamics, and policy implications. Food Policy 26:315-331. http://dx.doi.org/10.1016/S0306-9192 (01)00014-8

Benin, S., T. Mogues, G. Cudjoe, and J. Randriamamonjy. 2009. Public expenditures and agricultural productivity growth in Ghana. International Association of Agricultural Economists 2009 Conference. August 16-22, Beijing, China. \{online\} URL: http://ageconsearch.umn.edu/bitstream/51634/2/ public $\% 20$ spending $\% 20$ and $\% 20$ agricult ural $\% 20$ growth $\%$ 20in\%20Ghana benin.et.al IAAE revised.pdf 
Berry, S. 2009. Building for the future? Investment, land reform and the contingencies of ownership in contemporary Ghana. World Development 37(8):1370-1378. http://dx.doi.or g/10.1016/j.worlddev.2008.08.017

Blocher, J. 2006. Building on custom: land tenure policy and economic development in Ghana. Yale Human Rights and Development Law Journal 9:166-202.

Boamah, F. 2010. Competition between biofuel and food? The case of a jatropha biodiesel project and its effects on food security in the affected communities in Northern Ghana. Thesis, University of Bergen, Bergen, Norway.

Brown, D., and K. S. Amanor. 2002. Managing the environment. Annex 3 of the final technical report of project R7957. Overseas Development Institute, London, UK.

Bull, C. 2009. Norwegian land grabbers in Ghana - the case of ScanFuel. Spire, Oslo, Norway.

Center for International Forestry Research (CIFOR). 2011. Global Biofuel Information Tool. [online] URL: http://www. cifor.org/bioenergy/maps/

Chamberlin, J. 2008. It's a small world after all: defining smallholder agricultural in Ghana. Discussion Paper 00823. International Food Policy Research Institute, Washington, D. C., USA.

Clay, J. 2003. World agriculture and the environment: a commodity-by-commodity guide to impacts and practices. Island Press, Washington, D.C., USA.

Cotula, L., N. Dyer, and S. Vermeulen. 2008. Fuel exclusion? The biofuel boom and the poor's access to land. International Institute for Environment and Development, London, UK.

Cotula, L., S. Vermeulen, L. Leonard, and J. Keeley. 2009. Land grab or development opportunity? Agricultural investments and international land deals in Africa. International Institute for Environment and Development, London, UK.

Deininger, K. 2003. Land policies for growth and poverty reduction. World Bank Research Policy Report. World Bank, Washington, D.C., USA.

Ellis, F. 1998. Household strategies and rural livelihood diversification. Journal of Development Studies 35(1):1-38. http://dx.doi.org/10.1080/00220389808422553

European Space Agency (ESA). 2006. Globcover: global land cover project. ESA, Paris, France.

Fischer, G., E. Hizsnyik, M. Shah, and H. Velthuizen. 2009. Biofuels and food security: implications of an accelerated biofuels production. Summary of the OFID prepared by International Institute for Applied Systems Analysis. OFID Pamphlet Series. The OPEC Fund for International Development, Vienna, Austria.
Fold, N. 2008. Transnational sourcing practices in Ghana's perennial crop sectors. Journal of Agrarian Change 8:94-122. http://dx.doi.org/10.1111/j.1471-0366.2007.00164.x

Fold, N., and K. V. Gough. 2008. From smallholders to transnationals: the impact of changing consumer preferences in the EU on Ghana's pineapple sector. Geoforum 39 (5):1687-1697. http://dx.doi.org/10.1016/j.geoforum.2008.06.004

Food and Agriculture Organization (FAO). 2004. Ghana. Gateway to land and water information. FAO, Rome, Italy. [online] URL: http://www.apipnm.org/swlwpnr/reports/y sf/ Z _gh/gh.htm

Food and Agriculture Organization (FAO). 2008. The state of food and agriculture biofuels: prospects, risks and opportunities. FAO, Rome, Italy.

Food Information and Action Network (FIAN). 2010. Land grabbing in Kenya and Mozambique: a report on two research missions - and a human rights analysis of land grabbing. FIAN International Secretariat, Heidelberg, Germany.

German, L. A., G. C. Schoneveld, and E. Mwangi. In press. Contemporary processes of large-scale land acquisition by investors: case studies from sub-Saharan Africa. Occasional Paper, Center for International Forestry Research, Bogor, Indonesia.

Gibbs, H. K., A. S. Ruesch, F. Achard, M. K. Clayton, P. Holmgren, N. Ramankutty, and J. A. Foley. 2010. Tropical forests were the primary sources of new agricultural land in the 1980s and 1990s. Proceedings of the National Academy of Sciences 107(38):16732-16737. http://dx.doi.org/10.1073/ pnas.0910275107

Gordon-Maclean, A., J. Laizer, P. Harrison, and R. Shemdoe. 2009. Biofuel industry study, Tanzania: an assessment of the current situation. World Wide Fund for Nature, Dar es Salaam, Tanzania.

Grischow, J. D. 2008. Rural 'community', chiefs and social capital: the case of southern Ghana. Journal of Agrarian Change 8(1):64-93. http://dx.doi.org/10.1111/j.1471-0366.20 07.00163.x

Gyasi, E. A. 1996. The environmental impact and sustainability of plantations in sub-Saharan Africa: Ghana's experiences with oil-palm plantations. In G. Benneh, W. B. Morgan, and J. I. Uitto, editors. Sustaining the future: economic, social, and environmental change in sub-Saharan Africa. United Nations University Press, Tokyo, Japan.

Hayami, Y. 2010. Chapter 64 Plantations agriculture. Handbook of Agricultural Economic 4:3305-3322. http://dx.d oi.org/10.1016/S1574-0072(09)04064-X

Jaeger, P. 2008. Ghana export horticulture cluster strategic profile study. European Union All ACP Agricultural Commodities Programme (EU-AAACP), Brussels, Belgium. 
Jumbe, C. B. L., F. B. M. Msiska, and M. Madjera. 2009. Biofuels development in sub-Saharan Africa: are the policies conducive? Energy Policy 37:4980-4986. http://dx.doi.org/10 .1016/j.enpol.2009.06.064

Kasanga, K., and N. A. Kotey. 2001. Land management in Ghana: building on tradition and modernity. International Institute for Environment and Development, London, UK.

Kugelman, M., and S. L. Levenstein, editors. 2009. Land grab? The race for the world's farm land. Woodrow Wilson International Center for Scholars, Washington, D.C., USA.

Lansing, D., P. Bidegaray, D. O. Hansen, and K. McSweeney. 2008. Placing the plantation in smallholder agriculture: evidence from Costa Rica. Ecological Engineering 34 (4):358-372. http://dx.doi.org/10.1016/j.ecoleng.2007.08.009

Nonor, D. 2010. Massive jatropha farming threatens food security. Ghana Chronicle, 18 March. [online] URL: http://al lafrica.com/stories/201003180794.html

Nyari, B. 2008. Biofuel land grabbing in Northern Ghana. Regional Advisory and Information Network Systems, Ghana and African Biodiversity Network, Thika, Kenya. [online] URL: http://www.biofuelwatch.org.uk/files/biofuels_ghana.pdf

Peters, P. E. 2009. Challenges in land tenure and land reform in Africa: anthropological contributions. World Development 37(8):1317-1325. http://dx.doi.org/10.1016/j.worlddev.2008.08.021

Poulton, C., G. Tyler, P. Hazell, A. Dorward, J. Kydd, and M. Stockbridge. 2008. Commercial agriculture in Africa: lessons from success and failure. World Bank, Washington D.C., USA.

Quaye, A. K, C. A. S. Hall, and V. A. Luzadis. 2010. Agricultural land use efficiency and food crop production in Ghana. Environment, Development and Sustainability 12 (6):967-983. http://dx.doi.org/10.1007/s10668-010-9234-z

Reardon, T. 1997. Using evidence of household income diversification to inform study of the rural nonfarm labor market in Africa. World Development 25(5):735-747. http://d x.doi.org/10.1016/S0305-750X(96)00137-4

Renewable Energy Policy Network for the 21st Century (REN21) 2009. Renewables global status report: 2009 update. REN21 Secretariat, Paris, France.

Richards, P. 2005. To fight or to farm? Agrarian dimensions of the Mano River conflicts (Liberia and Sierra Leone). African Affairs 104(417):571-590. http://dx.doi.org/10.1093/a fraf/adi068
Schoneveld, G. C. 2010. Potential land-use competition from first generation biofuel expansion in developing countries. Occasional Paper 58, Center for International Forestry Research, Bogor, Indonesia.

Schoneveld, G. C., L. A. German, R. Andrade, M. Chin, W. Caroko, and O. Romero-Hernández. 2010. The role of national governance systems in biofuel development: a comparative analysis of lessons learned. Info Brief 35. Center for International Forestry Research, Bogor, Indonesia.

Schut, M., S. Bos, L. Machuama, and M. Slingerland. 2010. Working towards sustainability: learning experiences for sustainable biofuel strategies in Mozambique. Wageningen University, Wageningen, The Netherlands.

Seini, A. W. 2002. Agricultural growth and competitiveness under policy reforms in Ghana. Institute of Statistical, Social \& Economic Research Technical Publication 61. Institute of Statistical, Social \& Economic Research, Legon, Ghana.

Sulle, E., and F. Nelson. 2009. Biofuels, land access and rural livelihoods in Tanzania. International Institute for Environment and Development, London, UK.

Sutton, I. 1989. Colonial agricultural policy: the nondevelopment of the Northern Territories of the Gold Coast. International Journal of African Historical Studies 22 (4):637-669. http://dx.doi.org/10.2307/219058

Takane, T. 2004. Smallholders and nontraditional exports under economic liberalization: the case of pineapples in Ghana. African Study Monographs 25(1):29-43.

Toulmin, C. 2008. Securing land and property rights in subSaharan Africa: the role of local institutions. Land Use Policy 26:10-19. http://dx.doi.org/10.1016/j.landusepol.2008.07.006

Tripp, R. 1993. Invisible hands, indigenous knowledge and inevitable fads: challenges to public sector agricultural research in Ghana. World Development 21(12):2003-2016. http://dx.doi.org/10.1016/0305-750X(93)90072-H

Ubink, J. M., and J. F. Quan. 2008. How to combine tradition and modernity: regulating customary land management in Ghana. Land Use Policy 25(2):198-213. http://dx.doi.org/10. 1016/j.landusepol.2007.06.002

United States Geological Survey (USGS) 2011. Landsat Archive. USGS, Sioux Falls, South Dakota, USA. [online] URL: http://glovis.usgs.gov/ 
von Braun, J., and R. Meinzen-Dick. 2009. "Land grabbing” by foreign investors in developing countries: risks and opportunities. Policy Brief. International Food Policy Research Institute, Washington, D.C., USA.

Wardell, D. A. 2006. Collision, collusion and muted resistance - contrasting early and later encounters with empire forestry in the Gold Coast, 1874-1957. Working Papers on Ghana: Historical and Contemporary Studies 8. [online] URL: http:// www.helsinki.fi/project/wopag/Wopag8.pdf

Wily, L. A., and D. Hammond. 2001. Land security and the poor in Ghana: is there a way forward? A land sector scoping study. Summary. Prepared for the Department for International Development (DFID) Ghana Rural Livelihoods Programme. DFID, London, UK.

Wolter, D. 2009. Ghana: agriculture is becoming a business. Organization for Economic Co-operation and Development, Paris, France. http://dx.doi.org/10.1787/gen_papers-2009-5ks 9zs5gt1d2

Woodhouse, P. 2003. African enclosures: a default mode of development. World Development 31(10):1705-1720. http://d x.doi.org/10.1016/S0305-750X(03)00140-2

World Bank. 2010a. Rising global interest in farmland: can it yield sustainable and equitable benefits? World Bank, Washington, D.C., USA.

World Bank. 2010b. World development indicators. World Bank, Washington, D.C., USA. [online] URL: http://data.wo rldbank.org/data-catalog/world-development-indicators/wdi-2010

World Bank. 2010c. Ghana - Land Administration Project. Project paper 58615. World Bank, Washington, D.C., USA. [online] URL: http://tinyurl.com/3eq7f5c

Zaugg, J. 2009. Ethiopie. L'heure de la moisson a sonne. L'Hebdo 36.

Zoomers, A. 2010. Globalisation and the foreignisation of space: seven processes driving the current global land grab. Journal of Peasant Studies 37(2):429-447. http://dx.doi.org/1 $\underline{0.1080 / 03066151003595325}$ 